\title{
A Christian understanding of the significance of love of oneself in loving God and neighbour: Towards an integrated self-love reading
}

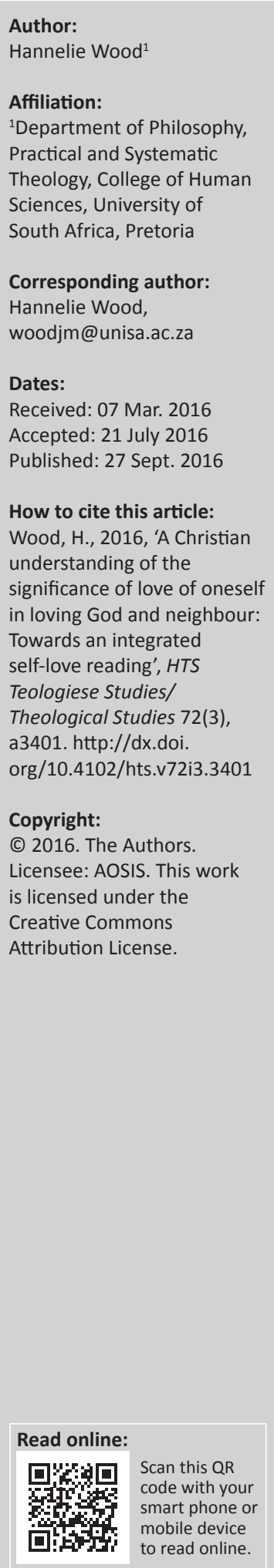

This article addresses the meaning of the great commandment of love (Mt. 22:35-40) with a focus on the understanding of self-love as considered within a Christian context. Christians in general understand the commandment as applying to love of God and one's neighbour. The reference to self-love tends to be ignored or misunderstood, especially when love of self is viewed in the context of the Christian virtues of humility and self-mortification. The concept of narcissism (self-preoccupation or self-glorification) has devastating effects on relationships with God, human beings and the world. In the Christian context self-love is not a third commandment and it is not clearly outlined in Scripture. Furthermore, the love of oneself seems to be the norm by which the love of God and neighbour are measured. It appears therefore that by bringing narcissism into the equation of self-love, a better understanding can be achieved of what a healthy Christian self-love should entail. Furthermore, a brief discussion on the views of the self as mind, emotions and will as well as agape, philia and eros is required for a proposed integrated self-love reading.

\section{Introduction}

There is no consensus in Christian circles on the issue of cogency of self-love in living the Christian life. Scripture does not present us with a clear-cut command to love ourselves. Neither does Scripture deal with it in such a way that we need not debate its meaning and significance for our every-day life-experience. It is therefore important within the present-day context to determine the nature of an acceptable understanding of self-love - if accepted as being of importance for living a Christian life - that does not violate core biblical teachings.

'Love' has many miens - sexual, parental and fraternal love being a few expressions of this phenomenon - each motivated by different desires, needs and hopes. We currently live in a world saturated with teaching and counselling on the need for a good self-image and sound self-esteem, which relate to a well-rooted love of oneself in coping with every-day life-challenges (cf. Altucher 2013; Brown 2010; Janzer 2013; Khoshaba 2012; Ravikant 2012). Self-love described by Deborah Khoshaba (2012:2) is 'a state of appreciation for oneself that grows from action that supports our physical, psychological and spiritual growth', or as explained by Cheryl MacDonald (2013):

If people have self-love, they respect their thoughts, feelings and beliefs and experience a deep sense of pride; a strut like feeling that says they have the right to have ideas, speak them, and expect others to be respectful. People that love themselves acknowledge and accept the fact that they have some faults and, for the most part excuse themselves. They learn from the mistakes made in life. (n.p.)

In Christian circles there are those who clearly share similar views on the need for a good selfimage, self-esteem, and self-love in our lives (Weaver 2002; Wegscheider-Cruse 2012). Others regard such viewpoints as unbiblical and lean towards the understanding that biblical love is selfless and unconditional, whereas the world's love is basically characterised by selfishness (Vitz 1995; Wommack 2014).

I shall, firstly, look at the dilemma with the self-love concept by briefly sketching past and presentday disagreements on it. This, however, is not an in-depth historical account of the concept; it merely wants to point the reader to the fact that the concept of self-love has been debated by many over many years and that many dilemmas surrounding it exist. Secondly, as the title also reflects, I shall focus on narcissism as pathology of self-love. Why? One of the manifestations - or maybe distortions - of self-love is narcissism. The narcissistic personality is judged by many to have an unhealthy form of self-love. Narcissism, as pathology of self-love and as a form of self-absorption, 
is claimed to have devastating effects on relationships with God, fellow human beings, and with the world. It is envisaged that by bringing this phenomenon into the equation a better understanding can be obtained of what healthy self-love entails. Thirdly, I will move on to discuss a biblical/ theological foundation for self-love. Lastly, I intend to formulate guidelines that, in my opinion, are of significance in the formulation of an integrated self-love concept.

\section{The dilemma with the self-love concept}

Undoubtedly we are dealing with adversarial viewpoints: those who affirm and those who reject the self-love concept. A wide spectrum of views exists on the issue of the acceptance or rejection of the notion of self-love in Christian teaching. For Aristotle (1985:146-147) self-love is a vicious act as well as a virtuous act. He contends that virtuous people are proper self-lovers who in the process of promoting the self will not harm others. Augustine (in O'Donovan 2006:92) states that '[p]erfect self-love is achieved only when God is loved to the fullest extent', and he interprets self-love as negative, neutral, and positive features of human beings' actions. Butler (2006:54) views self-love as an extreme or excessive self-love with no distinction between self-love and benevolence.

In 'The rot of religion ... the idolatry of self-love', Camp quotes from the book by Richard Alleine entitled Instructions about heartwork, who states that self-love is seen by some Christians as egoistic, a form of idolatry, the root of all evil, rebellion and disobedience to God. In addition, self-love is the love of the flesh and its affections and lust, a destructive plague that hinders true Christianity; it is a cancer of the church and the hallmark of the modern faith (Camp 2006:1). Nygren (1982:217) contends that Christianity does not recognise self-love to be a legitimate form of love, and that Christian self-love moves in two directions, namely towards God and towards neighbour and that self-love could easily result in the obstruction of our love of God and for our neighbour. For Tillich self-love is not the real enemy but rather selfishness and self-hate, neither of which should be confused with self-love.

Macmurray (1983:158) asserts that self-love always means loving another and we are not other than ourselves. Love is the reunion of what is separate or alien, and we are not separate from or alien to ourselves. He also states that self-love can be appropriate, but only as a means to serve and care for one's neighbour as the important other. Outka (1972:55-72) states that self-love has been regarded as 'wholly nefarious', normal, prudent, reasonable and requires neither praise nor blame. Furnish (1972:199) contends that self-love in theological works is not intended as a third commandment and that the biblical tradition assumes rather than instructs us to love ourselves. For Frankfurt (2004:68) self-love is the innermost and ultimate accomplishment of a meaningful and successful life. Vacek (1994:273) says that love of self is a third commandment alongside the love of God and the love of others. Self-love is important to how we relate to ourselves, and it denotes intraindividual participation (Vacek 1994:38, 74).

Walter Trobisch (1976:9) argues that one of the difficulties with the concept of self-love lies in the fact that it has a double meaning: self-acceptance as well as self-centredness and that persons can either love themselves selflessly or selfishly. 'Only the first is self-preserving, while the second is self-destroying' (Trobisch 1976:11). For Feleke and De Tavernier (2011:111-113) self-love, 'is in its distinctive nature, in and of itself, relational; it tends towards the good; and is to be originally found in God'. For feminists such as Lucy Irigaray (1993:60) the self-love concept means 'that to love self is essential for becoming female and the concept holds different meanings for men and women respectively'. For men 'self-love is established in relation to external reference points and that are the sex organ, other objects, and women' (Irigaray 1993:63).

The above-mentioned views are but a few, but clearly point us to a gamut of views that exists on the issue of the acceptance or rejection of the notion of self-love in Christian teaching. Narcissism as an unhealthy and distorted form of self-love will be touched upon below in order to portray a better understanding of what a 'healthy', acceptable self-love could be. This is done in order to present an argument for what I call an integrated self-love. Furthermore, it will be argued that there are sufficient grounds in Scripture for accepting self-love as a legitimate kind of love.

\section{Narcissism - a pathology of self-love}

Narcissism raises numerous questions concerning love, with many questioning whether what is described as love and love of self is in reality love. Introversion and overvaluation of the self is known as narcissism. The term derives from the Roman poet Ovid and his first-century story of Narcissus and Echo. Narcissus was the son of the river god Cephisus and the nymph Liriope. As a young fine-looking man Narcissus turned down many potential lovers, and after he rejected Echo, he was punished by the gods who made him fall in love with his reflection in a fountain, where he faded away and perished (Fascalini \& Grey 1993:200). The story of Narcissus is not that simple: it is not only a story of conceit and vanity; it is a story of confusion of the self and the notself (Lasch 1979:19).

Ellis (1898) was the first to use the term clinically to describe the condition 'auto-erotism'. Thereafter Freud ([1905] 1953) was the first to use the terms 'ego-libido' (self-love) and 'narcissistic libido' in his 'Three essays on the theory of sexuality'. During 1914 he wrote 'Narcissism: An introduction'. Freud's contribution on the self-love concept was mainly made through his concept of narcissism. Narcissism and self-love are closely related and synonymous in Freud's theory of self-love and his essay 'Libidinal types' (1931) depicts the narcissist as being independent, aggressive, extraverted, incapable to love and someone who attracts admiration and attention. 
It was Jones ([1913] 1951) who was the first to interpret narcissism as a character trait which he called the 'Godcomplex'. The narcissist according to him is inaccessible, selfadmiring, over self-assured, auto-erotic and visualises themself as being omnipotence and omniscience. Wälder (1952:264) published the first case study on the narcissistic personality wherein he stated that the narcissist has an attitude of superiority, one who is unsympathetic towards others and one who believes that they are unique and different from mankind. The psychoanalyst Wilhelm Reich (1972:218) published a book Character analysis in which he described the 'phallic-narcissistic character' with an aptitude of superiority, being arrogant and provocative with feelings of resentment towards others, and one who may have sadistic tendencies in relationships.

Horney (1939:90) developed narcissism as character trait by defining the many opposing forms of narcissism and she defined it as 'self-inflation' meaning that narcissists admire themselves for values for which no adequate foundation exists. Annie Reich (1960:217) describes the narcissists as those 'whose libido is concentrated on themselves with exaggerated, unrealistic infantile inner yardsticks'. In his works $(1966,1968,1971,1972)$ Kohut contends that narcissism is a normal part of development and that it is 'neither pathological nor obnoxious' (1966:243) but a result of a 'state of undifferential union with the mother, rather than a state of total self-absorption' (1966:245).

Kernberg (1975) believed that narcissism is a subtype of the borderline personality disorder but rejected the continuous view of narcissism. For him pathological narcissism is different than normal adult narcissism. Normal adult narcissism a the 'libidinal investment of the self' (1975:315) and involves the integration of 'good and bad self-images into a realistic self-concept' (1975:326).

A distorted view of the self may lead to narcissism as pathology of self-love with dire consequences for relationships with the self, God, and other human beings. Narcissists are considered to have an elevated positive and inflated selfconcept. They apply a range of intrapersonal and interpersonal strategies for maintaining positive self-views (Campbell, Rudich \& Sedikides 2002:359). For example, narcissists picture themselves as having excessive fame and power (Raskin \& Novacek 1991); they respond to opposing and threatening views with anger and self-enhancing attributions (Farwell \& Wohlwend-Lloyd 1998); they derogate those who pose threatening feedback (Kernis \& Sun 1994); and their interpersonal relationships lack in commitment and caring (Campbell \& Foster 2001). Neuhouser (2009) states that:

Love of self can become the sin of pride; it can degenerate into (or fail to develop out of) an amoral egoism; it can balloon into narcissism. All too often it makes us callous to the needs of others or overly sensitive to their assessments of our worth - or both. It can disrupt relationships and become an organizing principle in degenerate configurations of culture. (p. 279)
And Fergusson (2012) states:

Self-love can be presented as selfish and even narcissistic, and hence inimical to the love of one's neighbour in the outward orientation of the self. This can hardly be denied. Yet, when properly constituted, the love of one's self is correlative to the capacity to dispose oneself properly to the other, including God. (p. 12)

Sam Vaknin (2003), a self-proclaimed narcissist, states the following:

'Malignant Self-Love - Narcissism Revisited' was written under extreme conditions of duress. It was composed in jail as I was trying to understand what had hit me. My nine year old marriage dissolved, my finances were in a shocking condition, my family estranged, my reputation ruined, my personal freedom severely curtailed. Slowly, the realisation that it was all my fault, that I was sick and needed help penetrated the decades old defences that I erected around me. This book is the documentation of a road of self-discovery. It was a painful process, which led to nowhere. I am no different - and no healthier - today than I was when I wrote this book. My disorder is here to stay, the prognosis is poor and alarming. It is my contention that narcissism is the mental epidemic of the twentieth century, a plague to be fought by all means. (p. 10)

Vaknin (2003:548) believed that the belief that narcissists love themselves is a mistake since narcissists are not in love with themselves but with their reflections. Narcissistic love is directed towards a misdirected impression of the self, and since narcissists can only love impressions, they are not capable of loving themselves. Narcissistic love is always exchangeable with other emotions such as awe, respect, admiration and attention. When these actions are provoked in others - the others become loveable and loved. Thus, the narcissist's basic requirement is satisfied (Vaknin 2003:549). As in the case with the other, the narcissists go through the same cycle in their relationship with God but continue to pretend to love God and to follow God (2003:405). Narcissists become God 'by observing God's commandments, following God's instructions, loving, obeying, succumbing, merging, communicating, or even defying God'; They become God 'by the proxy of his relationship with God'. God is first idealised, then devaluated, then abused and 'one wonders if even God Himself can escape this classic pattern of behaviour of the narcissist' (Vaknin 2003:406). Thus, from a theological point of view, a narcissist wants to be omnipotent, omniscient, omnipresent, admired, much discussed, and awe inspiring. God resembles everything the narcissist ever wants to be - an idol (Vaknin 2003:466).

The experience of our humanness depends on our selfknowledge and the experience of ourselves. The difference between a healthy self-love and a distorted self-love lies in the ability to tell reality from fantasy and the ability to empathise and to love others (Vaknin 2003:5). The narcissist, incapable of true self-love, has an unhealthy and distorted idea of self-love as well as a distorted experience of the self (Vaknin 2003:548). But what is proper self-love really and what may we learn from Scripture? 


\section{Towards a biblical and/or theological foundation for self-love}

When Jesus was asked what the greatest moral commandment was, he replied by quoting two commands from the Old Testament:

'Love the Lord your God with all your heart and with all your soul and with all your mind'. This is the first and greatest commandment. And the second is like it: 'Love your neighbour as yourself'. (Mt. 22:37-39)

Many have understood this second commandment as including a command to love ourselves. However, this is a misreading of what it actually says. We are not commanded to love our neighbour and ourselves, but as ourselves. In other words, the statement naturally assumes that we have a certain desire for our own wellbeing, and the command is to have an equal concern for the wellbeing of others. Self-love is not a virtue that Scripture commends, but one of the facts of our humanity that it recognises and tells us to use as a standard. For the purpose of this article and the proposed notion of an integrated self-love, agape, philia and eros need to be defined.

\section{Self-love and agape, philia and eros}

Love can take on the form of agape, philia, and eros. Agape, philia, and eros are forms of love that we experience in everyday life, which give a specific meaning to the many relationships that we find ourselves in. But we have to determine the meaning of each of these forms of love in order to understand how relationships are affected by these specific kinds of love and how self-love fits into the bigger picture of our self-consciousness and our understanding of self-love (Wood 2008:108).

In Kittel's Theological dictionary of the New Testament (1977), agape is described as 'God's special love for an individual', and the noun agape expresses the 'love that makes distinctions, choosing its object and holding to it ... a free act, definitely chosen by the subject'. Agape is specially seen in God's love, the love of one on high, exalting those of low degree (humanity and creation). And in this context the Dictionary of the Bible describes agape as 'the deeper sense of spiritual affection', a love that unites God and humankind, soul and soul in divine communion (Hastings, Grant \& Rowley 1988). Agape is a form of sacrificial giving. It is God's way to humanity. It is God's grace, God's unselfish love, and it is given freely by God. Agape is sovereign in relation to its object and is directed to the good for those we stand in relationship with; it creates value in its object. There is no such thing as a good agape and a bad agape - there is only God's agape (Wood 2008:118).

In Kittel's Theological dictionary of the New Testament (1977), philia is defined as liking or caring, 'as of gods for men, of friend for friends, the love that is given to all kinds of human beings' a love 'from which a man can excuse himself, not an irresistible urge or frenzy'. Vine (1940) in his Expository dictionary says:
The use of philia in Peter's answers and the Lord's third question (Jn. 21:15-17), conveys the thought of cherishing the object above all else, of manifesting an affection characterised by constancy, from the motive of the highest veneration. (n.p.)

Fieser and Dowden (n.d.) in the Encyclopedia of philosopy use the term eros (Greek erasthai) to refer to that part of love constituting a passionate, intense desire for something; it is often referred to as a sexual desire, hence the modern notion of 'erotic' (n.p.; cf. Vacek 1994:150). The view that Christian ethics has been diminished by an eros-based ethics also exists (Nygren 1982:157). This means that more emphasis is placed on personal happiness or fulfilment. Human action is evaluated by the degree to which it leads to happiness of the self, fulfilment of the self, by possessing something, whether that something is God, a fellow human being or some other reality. Love as eros is always needy (Brümmer 1993: 110-120). Eros turned inward results into selfish desires and wishes, and eros love becomes a demanding, self-centred, and needy self-love.

\section{Self, self-love and 'mind', 'emotions' and 'will'}

The focus on views on self in philosophy, psychology and theology reflects the difficulty experienced in describing the meaning of self in its full depth and breadth. The various views on self in the field of philosophy recognise the importance of the human ability to think and reflect, in the experiencing of self. The mind seeks to understand through a process of reasoning what is experienced in terms of ourselves, others and the world around us. What we experience as human beings of ourselves and of others can only be experienced through our senses and it stands to reason that the mind and its functions, in the process of endeavouring to understand what we experience, is closely linked to our ability to see, hear, touch, taste and smell. This process also brings our emotions and our will into play. Emotions such as, hurt, fear, anger, joy, happiness, and peace influence the mind's response (Wood 2008:113).

Descartes' (1962:88) 'thinking-self' separates mind or soul from the bodily material world and has the effect that emotions, sensations, and feelings, necessary for selfreflection, can be neglected should his line of thought be followed. Although I agree with Descartes on the importance of humans' ability to think, and that this ability is closely linked with our experience of self, I want to emphasise that the experience of the self through the rational includes aspects such as feelings, perceptions etcetera. The self, as viewed only as a thinking entity, results in a viewpoint of the self that becomes de-personalised, de-individualised, not having the quality of being an integrated self. A self that only consists of a thinking component negates feelings, senses and experiences. Without senses, experiences, feelings, etcetera, the idea of a personal identity is not possible and the self as a rational and relational being becomes a thinking-self with thought as its only attribute. The rational side of the self is only one part of what constitutes the self. Pascal (in Levin 1992:9) is right in introducing the 'heart', descriptive of a 
deep-rooted sensitivity to the fundamentals of personal existence, in the process of experiencing self. So too Locke (1959) with his emphasis on the mind, body and sensations working together in creating awareness of self; Hume with memory and one's sense of personal identity; Kant with the noumenal self, self-in-self, only to be experienced in its effect in our lives; Hegel (1929) with his dialectical self-experienced in differentiation, integration and action, and last but not least, Kierkegaard (1944) with his awareness of self, formed in the tension created in the experience of relationship. It should be acknowledged that the ability to think, to reason, is of fundamental importance in experiencing self but it is always an ability that is closely linked and dependent upon so much more. It cannot be elevated to the only important reality in being human (Wood 2008:114).

In terms of the experience of an integrated self-love, mind, along with emotions and will is a core reality. Although the mind works through reasoning it works closely with one's emotions and will but the mind is the part where all experiences are intellectually observed and where one consciously and unconsciously learns to deal with the inner as well as the outer world. The mind, by the process of reasoning and analysis, assists us to learn lessons about ourselves and makes us conscious about the world. It stands to reason that everything we experience is fundamentally within the context of a specific relationship with something or someone. This relationship forms the context of the primary influence in the creation of an experience, but it is not the only influence in the creation of that specific experience. The whole net of relationships which we find ourselves in, in one way or another, influences our specific life-experiences, and thus also our experience of self. The lack of an integrated viewpoint of the self clearly has dire consequences for the understanding of the relationships we have with God, other human beings, ourselves, and the universe. If we do not experience self, we cannot experience anything else. In short: the ability to think, to reason, in other words, the rational, is of fundamental importance in discerning the importance of relationships and the development of relationships. It is an ability that draws on and is influenced by our personhood as a holistic experiential experience of past and present realities and future anticipations. Our evaluations, our perceptions of what we experience, are fundamental not only to how we relate to ourselves but to everybody and everything, God included (Wood 2008).

In the light of the above, the biblical teaching that God's love towards humans and all of creation is realised within the context of a covenant relationship, is a core truth. Love in Scripture is always within clearly defined relationships governed by certain distinctive responsibilities.

Interpretations of the statement in Matthew 22:39, 'You shall love your neighbour as yourself', in terms of understanding what is meant by 'as yourself', in general fluctuate between understanding it as either (1) a command to love oneself, (2) an indication that self-love 'is a desirable and necessary part of the emotional well-being of every individual, but not necessarily a command' (Makujina 1997:213) or, (3) natural and normal to love oneself. The first would then have the implied meaning of 'You shall love your neighbour just as you are to love yourself'; the second, 'You shall love your neighbour, understanding that you shall first learn what it means to love yourself'; and the third, 'You shall love your neighbour as you already do love yourself'. Views recognising self-love as important in the lives of Christians - whether as a command, as desirable and necessary, or as a given fact of life - have met, and are still being met, with a strong current of thought that finds no legitimate place for self-love in Christian life. ${ }^{1}$ I do not agree with the latter. In my opinion views that propagate self-love as a commandment and selflove as desirable or assumed very often flounder due to the poor theological milieu within which the interpretations are given - the latter often where great emphasis is placed on the interpretation of various texts in the Old and New Testament with deductions not guided by a satisfactory theological bedding for statements. The questions raised by reflection on self-love in a Christian context cannot be satisfactorily answered by a mere stringing together of texts in a simplistic proof-text method, says Gulley (2003:712-715). As point of departure in the discussion of a biblical-theological foundation for self-love, I choose to focus on Matthew 22: 36-40. It is a core statement in many of the discussions on self-love and it reflects, in my opinion, the core of a theological underpinning for self-love. The first that should be noted and considered in the forming of an understanding of the issue at hand is the context of Christ's answer.

\section{The law and the prophets}

In Matthew 22:36 'a lawyer' asked Jesus: 'Teacher, which is the great commandment in the law?' (Mt. 22:36). Responding to this question Jesus quotes from the Shema (Dt. 6:4-5) together with the commandment from Leviticus 19:18 that '[y]ou shall love your neighbour as yourself'. But Jesus also added that these two commandments are the sum of all the law and the prophets. This double love command for God and neighbour is according to Brady (2003) the hermeneutical key in the understanding of Scripture.

Jesus' answer indicates that he sees his statement on love - love of God and neighbour - revealing not only the main point of the 'law and the prophets' but its presupposition, its basis. 'The essence of the divine will is expressed in these two commandments', as Hill (1972:307) says, and this essence hinges on the love of God and neighbour. 'You shall love your neighbour as yourself' (Mt. 22:39), and then, naturally, also 'as yourself', has to be interpreted in this context. This immediately cuts off any interpretation of 'as yourself' as referring to the fact that it is natural and normal for humans to love themselves and that this becomes a kind of criterion for the love to be expressed in terms of the neighbour. Although it might be true that humans in general have a love of self, the spiritual milieu

1.The following are examples of the kind of statements referred to: Luke $9: 23$ and 24 , Romans $12: 10$ and 16, 1 Corinthians 13:5, Philippians 2:3-11, 2 Timothy 3:1-2. 
of Christ's statement, the root of the statement, is to be found in a defined relationship with God and neighbour. The interpretation of love of God, neighbour, and self, has to be interpreted within the context of 'all the law and the prophets'. The question posed to Christ and Christ's answer places the discussion of love squarely in this context. It is love understood and expected as revealed in the 'law and the prophets' - an understanding and expectation that has to conform to God's revealed understanding and expectation of what it should be and to which any expression of human self-love has to conform. Self-love as a natural phenomenon does not, as experience teaches us, automatically express God's precepts for a life in relation to the 'neighbour' as given in the teachings reflected in the 'law and the prophets'.

According to Donovan (2014), the Torah or law (Genesis Deuteronomy) is regarded as the most precious part of the Hebrew Scripture, and the prophets (Isaiah - Malachi) are the next most important. They clearly reveal and explain the gift of love and the demand of God's love. Donovan (2014) further points us to the fact that Jesus, by referring to the law and the prophets, says that these commandments encapsulate the greatest wisdom in Scripture and a guide to God's will. By loving God and doing what God wants us to do, and by loving our neighbour, we are complying with God's law. Hagner (1995) states:

Love of God and love of neighbor are quite different. Love of God is manifested by acts of obedience and worship that grow out of reverence for God. Love of neighbor is manifested by acts of kindness that grow out of concern for the neighbor's need. (p. 647)

Two possible readings of 'as yourself' remain: 'as yourself' as a command and 'as yourself' as a challenge in the light of God's revealed will to live such a life.

\section{Two commandments}

Christ describes 'You shall love the Lord your God with all your heart, and with all your soul, and with all your mind' as 'the great and first commandment' (Mt. 22:37-38), and immediately adds to this statement, 'And a second is like it' (Mt. 22:39). The two commandments - love of God and love of the neighbour - are clearly, as Barth (1960:216) points out, 'not identical' but 'separate' and 'conjoined'. The second of the two commandments also is no mere 'appended, subordinate and derivative command' (Barth 1960:216). 'You shall love your neighbour as yourself' (Mt. 22:39) in quality is 'like' the first (Lenski 1961:882). It is 'as important, of equal gravity', as Hill (1972:307) describes the relationship between the two. Quoting the second in addition to the first 'is in this instance not the fact that love to God includes love to our neighbour, which is true enough', says Lenski (1961:882), 'but that the quality and the high character of both commandments are "alike"', which leaves the two commandments in their natural order, "the one concerning God remains "first", and the other concerning man "second", for God is infinitely above man'.

\section{Barth (1960) is justified in writing:}

A true exposition can only speak of a genuinely twofold, i.e., a distinct but connected sphere and sense of the love required of man. It has reference to God, but also to the neighbour. It has the one dimension, but also the other. It finds in the Creator the One who points it to this creature, fellow-man. And it finds in this creature, fellow-man, the one who points it to the Creator. Receiving and taking seriously both these references in their different ways, it is both love for God and love for the neighbour. (p. 216)

And this gives credence to Hill's (1972:307) remark: 'Love of one's neighbour is not identified with love of God, but one is as urgent as the other.' Love that reflects God's precepts is a love that of necessity has to mirror the one in the other. The genuineness of the one without the other is suspect. Having said this, there is a second point concerning the relationship between the two commandments - an insight referred to by Barclay and by Schweizer - that needs to be highlighted. 'The basis of the love of man', Barclay (1972:308) points out, 'is firmly grounded in the love of God'. Schweizer (1975) remarks:

Jesus not only limits the necessary commandments to two, but by fusing those two he also prescribes how to perform the first: only the first commandment is called "great", but the second is equal to it, for one can love God only by loving one's neighbour. (p. 426)

If the above is accepted, 'as yourself' in the context of Matthew 22:37-40 has to refer to a kind of love one should have of oneself that (1) acknowledges the fact that the meaning and significance of one's life is to be found in loving God, and because of our love of God, living according to God's precepts and (2) that this kind of life challenges and, consequently, has to reflect love of God 'with all your heart, and with all your soul, and with all your mind' (Mt. 22:37) - a love of God that first and foremost (3) finds concrete expression in living, in one's many kinds of relationships with fellow humans, the kind of life that gives oneself a personal God-given integrity, a life (4) to which one is committed and which one cherishes. Such a person lives continuously in the shadow of this command and continuously strives to realise in his or her life that which God expects of one living a life that acknowledges Him as Lord. This way of life reflects a love of self that acknowledges that the meaning and significance of life, the 'essence' of life, is to be found in living in a committed relationship with God.

\section{Living in love}

Matthew 22:39 and statements such as to be found in Matthew 19:19, Mark 12:31 and 33, Luke 10:27, Romans 13:9, Galatians 5:14, Ephesians 5:28 and 33, and James 2:8 - all rooted in the Old Testament command given in Leviticus 19:18 - spell a Christian life as a life that of necessity is a life of love lived in accordance with the precepts of God. Loving God and living according to His precepts are two sides of the same coin (cf. Mt. 28:20; Jn. 14:15, 23, 31; 15:10, 14; Rm. 13:10; Ja. $2: 8 ; 1$ Jn. $2: 4-6 ; 3: 24 ; 4: 8 ; 5: 3 ; 2$ J.n 6). 'Love radicalises the 
law, showing the true extent and inner meaning of the specific (and, therefore, limited) and externalcommandments', as McQuilkin (1995:80) rightly indicates. God's precepts are love put in words; they define the duty of love in each of our spheres of responsibility as Christians (Henry 1957:261f.). The 'instructions for life in Scripture give substance and definition to the basic law of love' (McQuilkin 1995:28). Love of self reflects, in this context, not so much a commandment as an attitude concerning self that reflects an understanding and appreciation of oneself as a person living in the presence of God in an intimate relationship with God characterised by a love of God with all one's 'heart', 'soul' and 'mind' - a kind of love relationship that of necessity includes a love of one's 'neighbour' on the grounds that a love of God implies such a love. The only commands are that of a love of God and of the neighbour. Love of self is an orientation of one's life towards God and neighbour because of the special relationship one finds oneself in, a relationship chosen by one and a relationship cherished by one.

The radical nature of this love is to be seen in the life of Jesus of Nazareth, and the fact that Jesus' love for us is, as Smedes (1983:48) says with reference to John 15:12, 'God's norm for our loving', confronts Christians with the challenge of a life which was fully lived according to God's will in everything that He taught and did (cf. Jn. 4:34; 5:30; 6:38; Eph. 5:1-2). His life, in essence, confronts us with a life that has fully lived the injunction to be 'holy' and 'perfect' as God is 'holy' and 'perfect' (Lv. 19:2; Mt. 5:48; 1 Pt. 1:16). He 'the image of the invisible God, the first-born of all creation' in whom 'the fullness of God was pleased to dwell' (Col. 1:15, 19) not only challenges us to live such a life but also enables us to grow in a Christ-like life, in and through the Spirit, in everything that we experience and do (Col. 1:20-23; Rm. 8:28f.; Gl. 5:22-25). It is a life characterised by renewal in the image of our Creator (Col. 3:10 in the context of 3:1-17). The theological milieu of Matthew 22:39, and similar statements, fundamentally has to be the challenge of humans created to be the 'image' and 'likeness' of God - here understood in the sense of Barth's analogia relationis, stressing that in Christ through the Spirit it implies a humanising process that involves the human personality fully (Barth 1960). It is a humanising process with Christ as the example of what true humanity implies (Heyns 1974); a humanising process that is dynamic and reaches its ultimate reality in the consummation at the end of all times (Hoekema 1975).

Against this background I now turn to a discussion of selflove as an integrated experience of love of self.

\section{Towards an integrated self-love reading}

The route that I have taken has highlighted, firstly, the dilemma with the self-love concept. Narcissism, as pathology of love, was also brought into the discussion. The focus then shifted to self-love as a biblical concept with the meanings of such concepts as agape, philia, and eros and the self as 'mind',

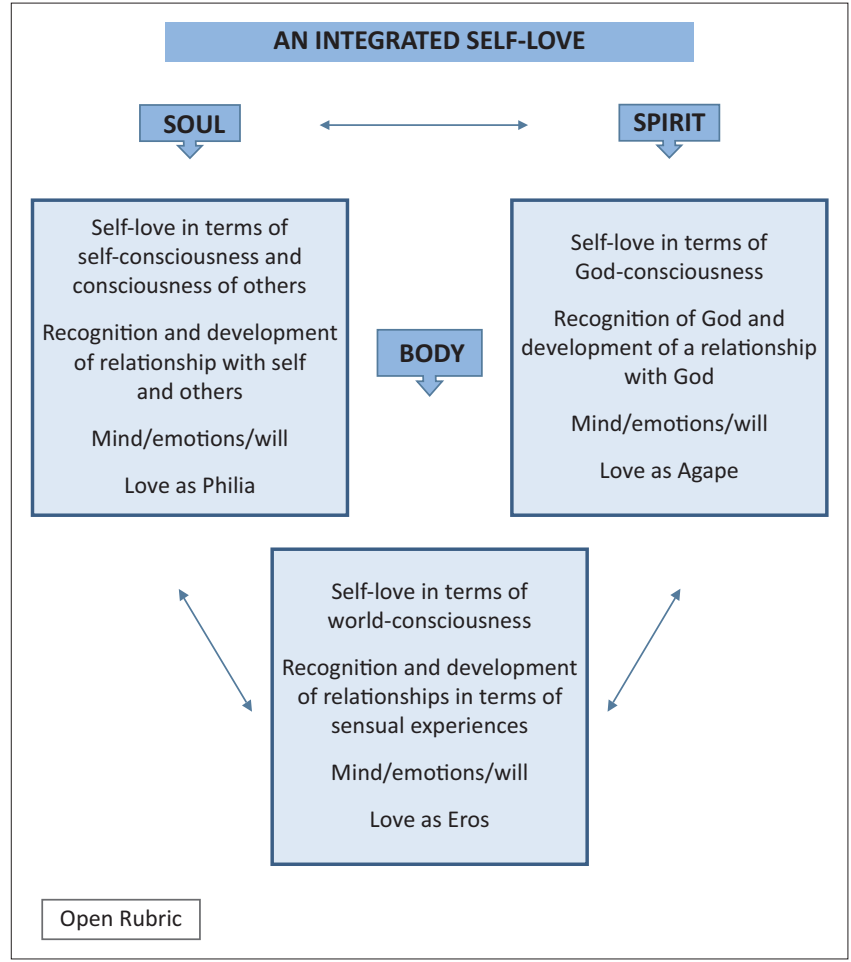

FIGURE 1: The above diagram sketches this experience (Wood 2008).

'emotions' and 'will'. Figure 1 sketches this experience by Wood (2008).

The experience of love in everyday life is diverse and complex in nature. Consequently, emphases and nuances in the description of love are numerous. A study of biblical statements on love reveals numerous insights that confirm these observations but there are also insights in biblical literature that add a dimension to the love experience not generally considered in everyday talk and study of love. Biblical teaching on love brings into the discussion of love the statements that affirm that our love can never be independent from God because of our origin as humans in the creative act of God that has made humans those creatures that are able to respond to God's love in a unique way.

This proposed concept of an integrated self-love highlights the fundamental difference between a healthy self-love and an unhealthy or narcissistic self-love. The difference, in essence, is to be found in the nature of the person's orientation in the various relationships was, is, and will be part of (Wood 2008:108).

In a healthy self-love, the experience of relationships is one of a sharing of our sense of self with others (Lowen 1983:31). It is a giving of self without violation of personal integrity, an integrity which is formed and experienced in a healthy relationship with oneself as a result of reciprocal healthy interaction with others and with reality as such (Fromm 1956:9-17). It implies an investment of self, a reality that is also uniquely portrayed in the biblical command to love our 'neighbour' as 'ourselves'. A healthy self-love is the result of a self open to reality in a communicative, mutually-giving, 
receiving, and co-operative love relationship with everything and everybody (Wood 2008).

A narcissistic self-love does not display the basic characteristic of a self open to reality. It mirrors a person's experience of himself or herself that is the result of an implosion and a collapse of the personal meaning of all relationships. Narcissism reflects not so much a true love of self than a love relationship with an image of self, a certain reflection of self, and thus portrays a lack of the true value of self (Lowen 1983:31). Narcissism - with reference to Matthew 22:39 - portrays the absence of a benchmark, in the relationship with oneself.

The acceptance of self-love as one of the important and needed expressions of love in a Christian context does not negate the fact that there are unhealthy forms, skewed forms, of self-love. Christians are not immune to numerable influences that could cause objectionable expressions of selflove. This, however, does not warrant dismissing the notion of self-love completely, as so often happened in the past, and still happens in our day and age.

There are no biblical grounds to claim that self-love should be shunned but there is certainly much written to warn against a self-love that is off track. Self-love, in a morally proper form, should be embodied in integrity and must be governed by our love for God and neighbour, in order for us to understand the relationships with ourselves, others and God. The notion of an integrated self-love is an attempt to describe a self-love that expresses a basic Christian belief for such an expression of love. Fundamental to an understanding of this concept is an understanding of the significance of relationships in life and existence and the position of self in the experience of relationships (Wood 2008). Allow me to explain.

Matthew 22:36-40 and corresponding statements on love refer to the importance and quality of relationships, in the light of God's precepts for relationships. The covenantal context of the expression of God's love towards humankind and vice versa points to the fundamental importance of relationships. All of life is fundamentally about relationships and we are not only part of numerous and varied relationships but we also need a wide variety of relationships, of a significant quality, for a meaningful life. Every facet of our lives is permeated by the influence of many types of relationships and each of these relationships influence, directly or indirectly, our psychological, spiritual as well as physical wellbeing (Wood 2008). We are very much the persons we are due to the physical, psychological and spiritual milieu resulting from the nature of our interaction with significant others. The full spectrum of possible experiences of relationships is possible only through the engagement of the whole of self, body, soul, and spirit, in interplay with reality (Wood 2008).

Mind, emotions, and will, play a decisive role in the creation and nurture of relationships. And here, once again, it is our total being, body, soul, and spirit that in a unique configuration of values, established through the kind of decisions that we make, determines the meaning of a given web of relationships. This configuration of values is fundamentally influenced by the nature of our life-orientation, namely, that it is basically an orientation influenced by a leaning towards 'body', 'soul', or 'spirit'. These orientations characterise fundamental differences in life-orientation (Wood 2008).

Relationships play a major role in how we perceive and interpret ourselves, directly or indirectly, influencing us to engage in some form of self-reflection. Self-love reflects the innermost perception we have of ourselves in and through the conscious or sub-conscious experiences of relationships we find ourselves in. This innermost perception greatly influences our ways of life. These realities are of fundamental importance in understanding the minutiae of a Christian self-love. The call to love God and neighbour is a call to respond to the presence of God and neighbour in accordance with the teachings of the 'law and the prophets' in regard to such relationships. This understanding of self is of fundamental importance in determining the nature of the self-love expressed. It acknowledges the possibility of expressing a self-love that does not reflect the precepts of God (Wood 2008).

In terms of the experience of an integrated self-love, mind, along with emotions and will are core realities. Although the mind works through reasoning, it also works closely with one's emotions and will. But the mind is the part where all experiences are intellectually observed and where one consciously and unconsciously learns to deal with the inner as well as the outer world. The mind, by the process of reasoning and analysis, assists us to learn lessons about ourselves and makes us conscious about the world. It stands to reason that everything we experience is fundamentally within the context of a specific relationship with something or someone.

The self in the context of a Christian theological anthropology is that of self as a specific consciousness of living as a person in the presence of the triune God. Existence is fundamentally determined by a specific kind of relationship with God that has its raison d'etre in God's will to create and have this unique relationship with His creation. In this relationship humans have the obligation to live in such a way as to reflect life as envisioned by God. The life and teaching of Jesus of Nazareth, in the presence and guidance of the Holy Spirit, enable humankind to live with God in His willed relationship.

The self in terms of philosophy and psychology points towards the self as being very much an individual's personal over-all interpretation or evaluation of his or her personal worth; his or her value, merit, significance mostly as an experience of personal value or significance, an inference of personal value or significance, in terms of the actions and reactions of others in a variety of relationships towards him or her. It is fundamental to identity. No one is born with a self-concept. The self-concept 
is formed and reshaped by repeated experiences with oneself and with significant others. The experience of self is significantly influenced by thoughts, processes of thinking, and the important role that memory plays in such thought processes. Thoughts and emotions are intertwined in that the one influences the other - emotions often proving to be the stronger of the two. The experience of self is significantly influenced by the unconscious (repressed thoughts or forgotten experiences). The experience of self significantly influences a person's motivation, either negatively or positively. There is a clear correlation between a person's experience of self and his or her actions - inaction also being a kind of action. Self significantly influences personal expression in word and deed.

\section{Conclusion}

What love entails is greatly influenced by the dominant views on love in the societies and cultures that we are part of and specifically by our religious convictions. Our views on love in general and self-love in particular, understood against the background of the proposed integrated self-love concept, are primarily influenced by our personal understanding of the meaning of love in our relationship with God. God's love is not a response to our attractiveness or our obedience and we can do nothing to attract the love of God nor can we persuade God to love us.

God loves. It is God's nature to love and that is why He is a loving God. This is the core of an integrated self-love. That is why it is required from us to love; it is our moral obligation and our ethical ideals that are interwoven to our relationship and connection with God. By loving the other we are virtuous; we are commanded by the Trinity to love God, our neighbour and ourselves. We love because He first loved us; therefore, we must love our neighbour as ourselves.

Christ presents us with much more than just a 'third commandment'. What he highlights in Matthew 22:36-40, and in other related pronouncements in Scripture, is the characteristic way of life of those with an intimate relationship with God. This presents a continuous challenge to live a life that reflects God's will as expressed in the 'law and the prophets'. This 'ideal' life reflects the core reality that grounds all that is experienced as God's guidance and teaching concerning life in His presence, namely, love. Love permeates every facet of Christian life and Christian teaching. Love is the very foundation of Christian life (1 Jn. 4:16).

Jesus' reply to the scribe's question on what the 'first of all commandments' was, links self-love inextricably with love of God and love of neighbour. It reflects in the context in which Jesus placed his answer a kind of love of oneself that:

1. acknowledges the fact that the meaning and significance of one's life is to be found in loving God, and because of our love of God, living according to God's precepts

2. that this kind of life challenges and, consequently, has to reflect love of God 'with all your heart, and with all your soul, and with all your mind' (Mt. 22:37)
- a love of God that first and foremost finds concrete expression in living, in one's relationships with fellow humans, the kind of life that gives oneself a personal God-given integrity

- consists of a life to which one is committed and which one cherishes.

As stated elsewhere, Scripture does not present us with a clear-cut directive to love ourselves, and neither does Scripture deal with it in such a way that we need not debate its meaning and significance for our everyday lifeexperience. Insights gleaned from a study of various contributions brought me to see self-love as a kind of love that conceptually portrays integration in our experience of us, as persons, of the various fundamental experiences of life (here portrayed as experiences of a 'body', 'soul', and 'spirit' nature) in such a way that an appreciation of ourselves as persons, a love of ourselves, develops that values the uniqueness of our personhood as a personhood that finds its meaning and significance in being beings in relationship with the whole of experienced reality, contributing positively, in and through our personal unique being and existence, to the wellness of reality, present and future. An integrated self-love is an experience of self, and thus of life and existence, a truly holistic experience. It spells a personal experience of life and existence that is grounded by a deep seated sense of inclusiveness of self, all and everything experienced in a multi-dimensional, multifaceted, reality as being of significance in and for personal life-expression and life-engagement (Wood 2008).

This I present for consideration in the debate on self-love in a Christian context.

\section{Acknowledgements Competing interests}

The author declares that she has no financial or personal relationships which may have inappropriately influenced her in writing this article.

\section{References}

Altucher, J., 2013, Choose yourself! Lioncrest Publishing, Nulkaba, Australia. Aristotle, 1985, Nicomachean ethics, transl. Terence Irwin, Hackett, Indianapolis, IN. Barclay, W., 1972, The Gospel of Mt, vol. 2, Saint Andrew Press, Edinburgh. Barth, K., 1960, Church dogmatics, T\&T Clark, Edinburgh.

Brady, B.V., 2003, Christian love, Georgetown University Press, Washington DC.

Brown, B., 2010, The gifts of imperfection, Hazelden, Center City, MN.

Brümmer, V., 1993, The model of love: A study in philosophical theology, Cambridge University Press, Cambridge.

Butler, J., 2006, Human nature and other sermons, Echo Library, Teddington.

Camp, S., 2006, 'The rot of religion ... the idolatry of self-love' [blog], viewed 01 September 2015, from http://stevenjcamp.blogspot.com/2006/08/rot-ofreligionthe-idolatry-of-self.html

Campbell, W.K. \& Foster, C.A., 2001, 'Narcissism and commitment in romantic relationships: An investment model analysis', Personality and Social Psychology Bulletin 28, 484-495.

Campbell, W.K., Rudich, E.A. \& Sedikides, C., 2002, 'Narcissism, self-esteem, and the positivity of self-views: Two portraits of self-love', Personality and Social Psychology Bulletin 28, 358-368.

Donovan, R.N., 2014, 'Matthew 22:34-46 Commentary (Bible study)', viewed 13 June 2016, from http://www.lectionary.org/EXEG_Engl_WEB/NT/01-Matt-WEB/ Matt\%2022.34-46.htm 
Descartes, R., 1962, A discourse on method, J.M. Dent \& Sons, London.

Ellis, H., 1898, 'Auto-eroticism: A psychological study', Alienist and Neurologist 19, 260-299.

Farwell, L. \& Wohlwend-Lloyd, R., 1998, 'Narcissistic processes: Optimistic expectations, favorable self-evaluations, and self-enhancing attribution', Journal of Personality 66, 65-83.

Feleke, M.K. \& De Tavernier, J., 2011, 'Selfishness, self-interest, and self-love', Vidyajyoti Journal of Theological Reflection, viewed 02 September 2014, from https://lirias.kuleuven.be/handle/123456789/310626

Fergusson, D., 2012, 'Theology and therapy: Maintaining the connection', Pacifica 26(1), 3-16.

Fascalini, J. \& Grey, A.L., 1993, Narcissism and the interpersonal self, Columbia University Press, New York.

Fieser, J. \& Dowden, B., n.d., 'Internet encyclopedia of philosophy. A peer-reviewed academic resource', viewed 25 August 2016, from http://www.iep.utm.edu/

Frankfurt, H.G., 2004, The reasons of love, Princeton University Press, Princeton, NJ.

Freud, S., [1905] 1953, 'Three essays on the theory of sexuality', in J. Strachey (ed.), The standard edition of the complete psychological works of Sigmund Freud, vol. 7, pp. 135-243, Hogarth Press Ltd, London.

Freud, S., [1914] 1991, 'On narcissism: An introduction', in J. Sandler, P. Fonagy \& E. Person (eds.), Freud's On narcissism: An introduction, Yale University Press, New Haven, CT.

Freud, S., [1931] 1959, 'Libidinal types', in J. Strachey (ed.), Collected papers, vol 5, ch. 23, Hogarth Press Ltd, London.

Fromm, E., 1956, The art of loving, Perennial Library, New York.

Furnish, V.P., 1972, The love command in the New Testament, Abingdon, Nashville, TN.

Gulley, N.R., 2003, Systematic theology: Prolegomena, Andrews University Press, Berrien Springs, MI.

Hastings, J., Grant, F.G. \& Rowley, H.H., 1988, Dictionary of the Bible, 1st edn., Scribner/Macmillan, New York.

Hagner, Donald A., 1995, Word Biblical Commentary: Matthew 14-28, vol. 33b, Word, Dallas, TX.

Hegel, G.F.W., [1837] 1929, Introduction to the philosophy of history, transl. J. Sibree, J. Loewenberg (ed.), pp. 338-443, Scribner, New York.

Henry, C.F., 1957, Christian personal ethics, Eerdmans, Grand Rapids, MI.

Heyns, J.A., 1974, Die mens: Bybelse en buite-Bybelse mensbeskouinge, Sacum Beperk, Bloemfontein.

Hoekema, A.A., 1975, The Christian looks at himself, Eerdmans, Grand Rapids, MI.

Horney, K., [1939] 1966, New ways in psychoanalysis, W.H. Norton \& Company, New York.

Hill, D., 1972, The Gospel of Mt., Oliphants, London.

Irigaray, L., 1993, An ethics of sexual difference, transl. Carolyn Burke and Gillian C. Gill, Athlone Press, London.

Janzer, A., 2013, True self-love: Heal the old wounds and the self-love will come on its own! Amazon Digital Services, Inc.

Jones, E., [1913] 1951, Essays in applied psychoanalysis, vol II: Essays in folklore, anthropology, and religion, Hogarth Press Ltd, London.

Kernberg, O., 1975, Borderline conditions and pathological narcissism, Jason Aronson, New York.

Kierkegaard, S., [1849] 1944, The concept of dread, transl. W. Lowrie, Princeton University Press, Princeton, NJ.

Kittel, G. et al., 1977, Theological dictionary of the New Testament, 10th edn., Eerdmans, Grand Rapids, MI.

Khoshaba, D., 2012, 'A seven-step prescription for self-love' [blog], viewed 02 December 2014, from http://www.psychologytoday.com/blog/get-hardy/201203/ seven-step-prescription-self-love

Kohut, H., 1966, 'Forms and transformations of narcissism', Journal of the American Psychoanalytic Association 14, 243-272.

Kohut, H., 1968, 'The psychoanalytic treatment of narcissistic personality disorders: Outline of a systematic approach', The Psychoanalytic Study of the Child 23 , 86-113.
Kohut, H., 1971, The analysis of the self: A systematic approach to the treatment of narcissistic personality disorders, International Universities Press, Madison, CT.

Kohut, H., 1972, 'Thoughts on narcissism and narcissistic rage', The Psychoanalytic Study of the Child 27, 360-400.

Lasch, C., 1979, The culture of narcissism: American life in an age of diminishing expectations, W.W. Norton and Co, London.

Lenski, R.C.H., 1961, The interpretation of St. Mt's Gospel, Augsburg Publishing House, Minneapolis, MN

Levin, J.D., 1992, Theories of the self, Hemisphere Publishing, London.

Locke, J., [1690] 1959, An essay concerning human understanding, Dover, New York.

Lowen, A., 1983, Narcissism: Denial of the true self, Macmillan, New York.

MacDonald, C.A., 2013, 'How self love and boundaries mix', Health Psychology of San Diego, Oceanside, CA, viewed 15 May 2016, from http://healthpsychology.org/ how-self-love-and-boundaries-mix/

Macmurray, J., 1983, Persons in relation, Humanities Press, Atlantic Highlands, NJ.

McQuilkin, J.R., 1995, An introduction to biblical ethics, Tyndale House Publishers, Inc., Carol Stream, IL.

Makujina, J., 1997, 'The second greatest commandment and self-esteem', The Master's Seminary Journal 8(2), 211-225.

Neuhouser, F., 2009, 'Rousseau's theodicy of self-love: Evil, rationality, and the drive for recognition', Notre Dame Philosophical Reviews, reviewed by Wayne M. Martin, Oxford Úniversity Press, Oxford.

Nygren, A.E., 1982, Agape and eros: The Christian idea of love, transl. Philip S. Watson, University of Chicago Press, Chicago, IL.

O'Donovan, O., 2006, The problem of self-love in St. Augustine, Yale University Press, New Haven, CT.

Outka, G., 1972, Agape: An ethical analysis, Yale University Press, New Haven, CT.

Pascal, B., 1966, Pensées, Penquin, London.

Raskin, R.N. \& Novacek, J., 1991, 'Narcissism and the use of fantasy', Journal of Clinical Psychology 47, 490-499.

Ravikant, K., 2012, Love yourself like your life depends on it, Amazon Digital Services, Inc.

Reich, A., 1960, 'Pathological forms of self-esteem regulation', The Psychoanalytic Study of the Child 15, 215-232.

Reich, W., [1933] 1972, Character analysis, 3rd edn., Farrar, Straus, \& Giroux, Inc. New York.

Schweizer, E., 1975, The Good News according to Mt, SPCK, London.

Smedes, L.B., 1983, Mere morality: What God expects from ordinary people, Eerdmans, Grand Rapids, Ml.

Tillich, P., 1954, Love, power, and justice: Ontological analyses and ethical applications, Oxford University Press, New York.

Trobisch, W., 1976, Love yourself, Inter-Varsity Press, Downers Grove, IL.

Vacek, S.J., 1994, Love, human and divine: The heart of Christian ethics, Georgetown University Press, Washington DC.

Vaknin, S., 2003, Malignant self love, 1st edn., A Narcissus Publications Imprint, Prague.

Vine, W.E., 1952, Expository dictionary of New Testament words with their precise meanings for English readers, Oliphants, London.

Vitz, P.C., 1995, 'The problem with self-esteem', viewed 02 December 2014, from http://www.catholiceducation.org/en/education/catholic-contributions/theproblemwith-self-esteem.html

Wälder, R., 1925, 'The psychoses: Their mechanisms and accessibility to influence', International Journal of Psycho-Analysis 6, 259-281.

Weaver, D.F., 2002, Self-love and Christian ethics, Cambridge University Press, Cambridge, UK.

Wegscheider-Cruse, S., 2012, Learning to love yourself: Finding your self-worth, Health Communications, Deerfield Beach, FL.

Wommack, A., 2014, 'Psychology vs. Christianity', viewed 02 December 2014, from http://www.awmi.net/reading/teaching-articles/psychology_christianity/

Wood, J.M., 2008, 'The Christian concept of self-love and the narcissistic self: A theological approach', Unpublished MTh thesis, University of South Africa. 